\title{
Echoes of lithoko in modern Sesotho poetry: An intertextual perspective
}

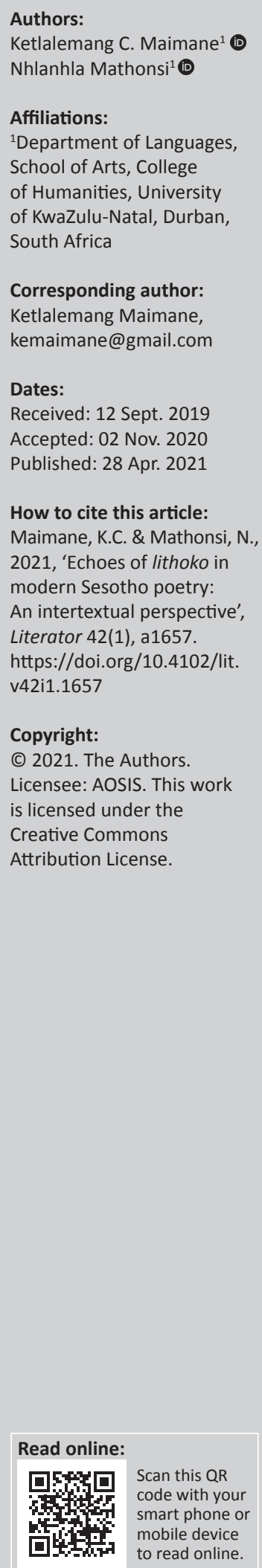

It is the view of this article that since its inception in the early 1930s, modern Sesotho poetry (MSP) has played host to other literary genres; amongst them lithoko. This article therefore regards some of the content in MSP, reflective of and traceable back to lithoko. Amongst others, these echoes are in the form of eulogues and communicative devices. Nevertheless, the reviewed literature gives no indication of any scholar exploring this literary relationship between modern Sesotho poetry and lithoko. Hence this article sets out to explore this intertextual relationship between lithoko as the literary parasite, and MSP as the host. In doing this, firstly the article establishes what it considers as lithoko content in MSP, which is classified under eulogues and lithoko communicative devices. Then, from the Sesotho poetry texts within the clusters into which the texts under study have been divided, content that is regarded as the echoes of lithoko in MSP is identified and discussed. Using intertextuality as a guiding theory, the first category of eulogues is considered. The article reveals that this mother-child literary relationship between these two phenomena is manifested in a number of ways in MSP. This revelation goes a long way in not only opening up perceptions of both scholars and analysts of modern Sesotho poetry with regard to the structural content, but also poetic dynamics of the genre. Furthermore, the intertextual disclosure helps poetry scholars to have a full appreciation of MSP as literature and of its literariness.

Keywords: modern Sesotho poetry; reflective; lithoko; intertextual perspective; poetry.

\section{Introduction}

What is known as modern Sesotho poetry (MSP) today dates as far back as 1931 with the first publication of the poetry anthology titled Lithothokiso tsa Moshoeshoe le tse ling [Poems on Moshoeshoe and other poems] by Bereng. Bereng's poetry marked the birth of a new phenomenon in the history of Basotho literary works as the poetry known and practised before then was the oral lithoko, ${ }^{1}$ which existed and was performed in various forms.

Along with Bereng's (1931) ground-breaking poetry anthology, the new MSP was born. In our view, MSP defines both the tendencies and the kind of writing that modern Basotho poets produced from 1931 to the present day. This view is derived from the fact that the literary tendencies after 1931 produced poetry that constitutes a divergence from the known lithoko. This poetry is characterised by a new outlook with a new poetic expression constructed from aspects of form, style and content material derived from cultural and religious, as well as Western poetic traditions. This is also a poetry with a new purpose, subject matter and themes, and as such, it tries to experiment with borrowed poetic techniques such as rhyme and metre. Most importantly, the written form of the poetry bestows upon it a new face.

Sesotho poetry is now a literary term used to describe a literary work of art referred to as thothokiso/ reneketso, which is a poetic description of either animate or inanimate objects, events or situations and even human feelings or experiences at times.

Content or subject-matter, on the other hand, can be defined as what a literary text talks about or embodies; the issue(s) raised or a matter that a literary work of art contains. Tšiu (2008:132), though admitting that the word content is preferred to subject matter by some writers, defines subject matter in terms of oral-formulaic composition, and states that it refers to what is contained in the seroki's (one who recites lithoko) declaration, chants, praise, which forms the essence and the essential material on which the oral composition such as lithoko is dependent and without which it loses its (literary) essence of being. The importance attached to content as Tšiu (2008) argues is

1.Maimane and Mathons (2016:12-23) - for the reasons outlined and evidence provided for in this article, calling lithoko praise poetry fails to do them justice given their diverse nature. Therefore, the term lithoko is retained. 
that it determines the form of a literary genre. It is through the content of a literary genre that one is able to say whether or not such a genre is a thoko, a sefela [a mine worker's chant] or a seboko [a family ode]. In lithoko, for instance, as Tšiu (2008) further argues, 'subject-matter, the hero/es, the enemy, the battle field', historical and war references constitute lithoko. This is supported by Lenake (1984:15) who also regards subjectmatter as relating to 'what is being said in a poem'. This means that if a poet makes reference to a historical fact, hero/heroine, battlefield, warring factions, even the bone of contention amongst others, that constitutes the content of the poem.

When this content, whose origin is lithoko, is found in another genre such as MSP, it is referred to as an intertext of lithoko. In this case, as per the above examples, content is what is contained, and is not only manifested in but also forms the essence of MSP. To some extent, MSP is dependent on it, the origin of which can be traced back to lithoko. This content constitutes the soul whilst structure constitutes the body of MSP.

What is identified and discussed as content in this article comprises eulogues ${ }^{2}$ or lithoko-names and their allusions in MSP. These names, amongst others, are of people, places, weapons used and battlefields, even those used as historical references; and as Tšiu (2008:145) points out, '... the heroic deeds of the chiefs or warriors in the wars or battles in which they took part', as well as the causes for those battles or wars.

The following approach is adopted for the analysis: A poem from the selected texts (those published between 1931 and 2010), from which the eulogues are identified, is selected. The selection of the poem is based on the presence of the sought eulogues in that poem. Having identified the relevant eulogues, they are then classified and discussed under the eulogical categories according to Kunene (1971:35-52). Relevant examples of the manifestations of the sought intertexts are drawn from the selected poems across the strata per individual categories of eulogues alongside their counterparts from lithoko. The identified texts are then subjected to intertextuality as a theoretical framework.

\section{Review of related literature}

Lenake (1984) and Khaketla (1985) are some of the scholars whose studies on MSP have been critically considered for this article. None of these critics looked at MSP as a newly reconstructed poetic identity through its relationship to lithoko.

In the preface of his poetry anthology, entitled Lipshamathe 'Breathtaking items', Khaketla (1985) gives a brief descriptive analysis of the nine books of poetry published between 1931 and 1951 by Bereng (1931), Mocoancoeng (1947), Mokorosi (1951), Mopeli-Paulus (1945), Ntsane (1946), Sekoai (1950), Selane (1942), Sentšo (1948) and Tšosane (1949). In his appreciation of these works, Khaketla considers the following

2.Kunene (1971:xxii-xxiii) - eulogues is used to refer to the different kinds of praise reference: names such as deverbative nouns describing the hero according to his actions or metaphorical names comparing the hero to natural phenomena'. about the genre - MSP: its origins, definition and issues of imagination, rhythm and feeling as well as the poetic language used by these Basotho poets.

Khaketla (1985) does not touch on issues of intertextuality. However, his discussion on origins and definition of MSP as well as the poetic language used in this poetry, inform this article in issues relating to origins, definition and the poetic language used in MSP. On the other hand, poetic language contributes in shedding some light when the article considers the linguistic richness brought about by the inclusion of lithoko content in MSP by Basotho poets.

One of the critics who made a significant contribution to the field of poetry is Kunene (1971) through his book entitled The Heroic Poetry of the Basotho. In his analytical description of the heroic poetry, Kunene discusses various aspects that not only feature in the rendition and the making of such lithoko, but also in the creation of MSP as well. Such aspects include two types of eulogues, namely: naming and associative eulogues, which are further subdivided into deverbative, metaphorical and descriptive, under naming, as well as relatives, peers and genealogical associations, under associative eulogues (Kunene 1971:35-52). These are the poetic elements this article discusses as echoes of lithoko in MSP.

Kunene's study is about lithoko not MSP, which is the interest of this paper. However, since eulogues are some of the intertextual features in MSP, Kunene's definition, classification and discussion of eulogues inform this study in that regard. One of the key concepts this article adopts is Kunene's (1971:xxii) use of the term eulogue, instead of eulogy, as reference to the different kinds of lithoko names. Such references are names in the form of deverbative nouns describing the hero in accordance with his deeds, or metaphorical names where a hero is compared to some natural phenomena, as well as naming a hero by associating him with either some individual or place.

\section{Theoretical underpinnings}

The discussion and analysis of examples of echoes of lithoko in MSP are founded on intertextuality. The birth of intertextuality came as a result of Kristeva's (1966) attempt to combine both Saussurean and Bakhtinian linguistic and literary theories respectively. Kristeva produced the first articulation of intertextual theory, in the late 1960s. However, the use of the term intertextuality was first seen with the post-structuralist theorists and critics (amongst them, Roland Barthes) in their endeavours to challenge notions of stable/constant as against the ever-changing and plurality in meanings as well as impartial interpretation (Graham 2000:2-3, 2003:79). As Graham (2000:11) observes, neither Saussure nor Bakhtin makes use of the term and so, most people would credit Julia Kristeva with being the inventor of 'intertextuality'.

Kristeva's first and primary focus was to provide a descriptive, ontological vision and explanation on how 
texts are composed. Her argument being that every text is constructed as an assortment of quotations; and that texts construct their being by absorbing and transforming others which came before them (the newly constructed ones). A text is therefore, according to Barthes 1977 (cited in Allen 2011:73) regarded as a construct of numerous writings, drawn from many cultures. In accounting for the importance of intertextuality as a literary term, Graham (2000:5-6) draws our attention to the facts surrounding its literary position and implications in terms of other preceding as well as coexisting notions, and he argues that intertextuality foregrounds notions of how texts relate, connect and depend on one another in modern cultural life.

It is on the basis of this 'relationality, interconnectedness and interdependence' of texts that, according to Graham (2000:5-6) in the Postmodern era, theorists often regard it no longer possible to speak of originality or the uniqueness of the artistic artefact, whether it is a painting or a novel, as every artefact is undoubtedly a product of debris borrowed consciously or unconsciously, directly or indirectly by the present artist, from the already existent work of art. As a result, 'every text has its meaning, therefore, in relation to other texts' (Graham 2000:6). Modern Sesotho poetry in this case is therefore viewed as an intertext assembled from bits and pieces of already existent lithoko, amongst others.

Abrams' (1999:317) definition, which is more apt, regards the term as denoting the multiple ways in which any one literary text echoes or is a construct from other texts, either through its overt or covert citations or allusions; or by the assimilation of the feature of an earlier text by a later text, or simply by participation in the common stock of linguistic and literary codes and conventions that are already established and constitute the discourse into which we are born.

Bazerman (2005:3) distinguishes six levels of intertextuality for purposes of analysis. He says that these are levels at which a text overtly echoes another pre-existent text and uses it as a literary parasite. According to Bazerman (2005:3-4) the six levels of intertextuality may be echoed in a text in the following ways:

- Where the text uses prior texts as a source of meaning to be used at face value; in which case, the text borrows statements from the source, repeating them as authoritative information for purposes of constructing itself.

- The text borrowing 'explicit social dramas' from prior texts engaged in discussion.

- Where the text overtly uses other textual material for purposes of background, support and contrast.

- Where a text, in a less explicit manner, echoes beliefs, traditions, ideas or statements generally known to the readers who may attribute such texts to a particular source, or regards them as common knowledge.

- The use of some readily identifiable linguistic registers and genres that can be associated with a particular social world.
- Using a particular language and language form, a text borrows from the available and prevalent language resources without necessarily particularising the intertext.

These levels of intertextuality can be explored through certain techniques representing the words and utterances of others. These techniques range from direct and indirect quotations, 'mentioning of a person, document or statements'; 'comment or evaluation on a statement, text, or otherwise invoked voice'; to more implicit ones 'using recognisable phrasing, terminology associated with specific people or groups of people or particular documents' and 'using language and forms that seem to echo certain ways of communicating, discussions amongst other people, types of documents' (Bazerman 2005:5).

Porter (2009) refers to the six levels as two types of intertextuality; iterability and presupposition described as "citation in its broad sense or "repeatability" - anything that might be considered "borrowed" in any sense, even if acknowledged'; whilst:

$[P]$ resupposition on the other hand refers to assumptions a text makes about its referent, its readers, and its context-to portions of the text which are read, but which are not explicitly there. (p. 1)

This article contends that MSP is no exception in that Sesotho poets, consciously and unconsciously, have demonstrated some of these levels of intertextuality. For purposes of analysis of MSP therefore, these levels will inform arguments and help with specifics when it comes to the identified intertexts or cases of borrowing, and intertextual influence.

Therefore, in order to address issues of meaning and interpretation of intertexts, as well as contextualising them, the analysis will engage intertextuality as an interpretative method in various eulogical echoes within MSP.

\section{Analysis \\ Eulogues in modern Sesotho poetry texts}

Eulogues are defined by Damane and Sanders (1974:54) in terms of some of the linguistic qualities whose frequent use in lithoko accords them some distinctive characteristics. They are basically references to individuals or broadly speaking, animate and inanimate objects other than in their familiar appellations in the lithoko context. As Damane and Sanders (1974:40) observe, amongst the Sotho communities, a single man may have several names he is known by, other than that given to him at birth. For example, Chief Moletsane of Bataung, who was born Makhothi, came to be known as Moletsane, the name derived from the beads called moletsa, which he wore whilst growing up amongst the San community. The same man is later referred to by several names including 'Tebe-tebe' [slough], 'Ramoeletsi' [father of Moeletsi], 'Letšoara' [the gripper], 'Tšiame' [the sad one], 'Mapaholle' [one who exposes], 'Mohatsa Motlaho' [the husband of Motlaho], 'Le-lelekisa-tšoana' [one who chases 
after black cows], amongst others (Mangoaela 1957:2-4). Whilst Damane and Sanders (1974:40) refer to these references as praise-names, Kunene (1971:14) uses the term eulogues and provides a detailed study on their nature, formations and classification, which this discussion aligns itself with.

On another account, eulogues also appear as allusions to historical events and occasions. Cuddon (1998:27) defines allusion as 'an implicit reference' either to a literary work or art, an individual or incident, which is more often some sort of a call intended for a reader to share in the experience with the writer. This means that the lithoko-names and some oral-formulaic structures MSP uses make an indirect reference, not only to some historical facts about certain individuals, but also to some incidents and experiences from the past to share with the reader. According to Kunene (1971:38), these facts about certain individuals can also be in the form of associative references relating the hero to his descent and place of origin. Along with eulogues or lithoko-names alluding to descent, place of origin, identified and discussed as part of lithoko content in MSP, the aspect of historical allusions to certain events, occasions and stories is also considered.

By virtue of being based on and giving account of historical events and occasions, lithoko are regarded as a traditional way of keeping history alive and passing it on to following generations (Ogunjimi 2005:166, 207). Through the historical references it makes, MSP is viewed as echoing lithoko in this respect as manifested in the poetic segments to be presented below. These insights are therefore regarded as the manifestations of the interconnectedness between that which Shanoda (2012:83) labels the third type of intertextuality 'texts that make reference to and use recognised clusters of literary conventions'.

The otherness, in which MSP adopts the same naming style as exemplified from lithoko above, is manifested in Khaketla (1985:61-62). As in lithoko, in referring to the train by calling it terene [train], a term used by the Sesotho speaking communities, the poet refers to it in other names such as 'Lehlanya' [the lunatic], 'Lefokololi' [the millipede], 'Sebaka-meholi' [the fog generator], 'Semetsa-machaba' [the devourer of nations], amongst others. Details in terms of function, significance and importance of these references are dealt with under the discussion below.

Kunene (1971:35-52) classifies and discusses eulogues in two main categories; being the naming and associative eulogues. This article looks into the first part of the naming eulogues.

\section{Naming eulogues in modern Sesotho poetry}

Naming eulogues are further sub-divided into five sub-groups, though only the first two are considered in this article:

1. Deverbative eulogues

2. Metaphorical eulogues - under which there are also:

a. Descent and

b. Place of origin.
According to Kunene (1971:35), naming eulogues are those terms coined as additional names a person is also known by. As Kunene (1971) observes, for each of these names, different conditions, as determined by the seroki's view, have been at play inspiring the coinage of such names. Modern Sesotho poetry has borrowed texts from almost all the naming eulogues from their five sub-categories as used in lithoko. These coinages, amongst others, are inspired by the action(s) someone has performed, the result of which is what Kunene (1971) terms deverbative eulogues. In some cases, these coinages are indicative of the nature or characteristics, the history behind and the importance of the one being referred to.

\section{Deverbative eulogues in modern Sesotho poetry}

Deverbative eulogues are defined as 'eulogues which are derived from verbs' (Kunene 1971:35). These are usually action-related names, referring to the hero's actions. For example, the name Mapaholle for Chief Moletsane is derived from the predicate, / ho paholla/, which Bereng and Lehloenya (2006:69) describe as '... ho ntša ntho bothateng moo e parakisitsoeng' [to bring something out of a place where it has been well concealed]. The name, according to the oral history connected to Moletsane's lithoko, is based on Chief Moletsane's action of discovering and bringing out the black cows that belonged to Batlokoa, where they had been well hidden during Ntoa ea Montša (Montša war - the battle in which Chief Sekonyela of Batlokoa was driven out of his fortress), as the battle between Batlokoa and Basotho in 1828 where the latter were assisted by Bataung, was known. After the incident, Moletsane described himself as Mapaholle from his action of ho paholla [exposing or disclosing] the hidden cattle. Not only does the name declare Chief Moletsane's heroic deed, but it also conjures a historical event of the battle between Chief Sekonyela of Batlokoa and Bataung with Chief Moletsane. The name is further indicative of Moletsane's ability and skill in uncovering hidden or concealed items. The following are extracts of deverbative eulogues from some of the poems selected from poetry texts. The names are discussed in terms of actions they convey with regard to their bearers.

Bereng (1931:3-26) has coined several names for Lepoqo, well known as Moshoeshoe 1, the founder of the Basotho nation. These names are derived from verbs and are based on different actions associated with and said to have been performed by Moshoeshoe 1 in his time. These names can also be classified into two groups, namely: those which are one word, such as Moshoeshoe 1, Thesele and Sefabatho [The one who feeds people] and those which are either in a form of compounded nouns or adjectival clauses, such as: 'Mo-roba-rumo la Chaka a ba le khomeletse' [The one who breaks and mends Chaka's spear], 'Mokelli oa basotlehi' [The gatherer of the poor], 'Musi oa Basotho le Matebele' [The ruler of the Sotho and Ndebele], 'Mofani oa limpho tsa borena' [The giver of Chieftainship gifts], 'Mothehi le mohahi oa Lesotho' [The founder and builder of Lesotho], 'ea kentseng leseli lefifing' [The one who brought in the light to darkness]. The names given above are a few examples of the many deverbative names used by Bereng (1931:3-26) in describing Moshoeshoe 1. 
The name Thesele as an example is a noun formation from the verb 'thesela', which Damane and Sanders (1974:66) define as 'to thump, butt, smash - indicating how he dealt with his enemies in battle'. The word can also mean to push over/ aside or out of one's way, which could mean that besides having to deal with his enemies, he was also able to push aside most of the challenges such as lifaqane, cannibalism, tribalism and wars that faced his people and shaped the people into the nation that they are today. The most significant threat that he was able to push aside as the name suggests was the annexation of Lesotho by the Orange River Sovereignty (the present Free State). For instance, according to Damane (1998:82) upon realising that the Free State government of the time, through Sir Philip Wodehouse, was on the verge of annexing Lesotho during the Seqiti War, on 9 December 1867 Moshoeshoe 1 asked Queen Victoria of England to accept Lesotho as a British protectorate. Subsequently, on 12 March 1868 Lesotho was declared a British protectorate, and so was saved from the looming annexation. Actions surrounding these names also conjure some historical events that took place during Moshoeshoe 1's time as evidenced in the example given above.

The name Thesele therefore is an intertext that has been directly lifted from Moshoeshoe 1's lithoko in Mangoaela (1957:5-8). Modern Sesotho poetry has borrowed and used this thoko item as a readily identifiable linguistic register adopted from lithoko as another genre and as such, the name is associated with lithoko in the oral traditional world (Bazerman 2005:3-4).

Modern Sesotho poetry extends the coinage of action-related names for female folk as manifested in Khaketla (1963:66-68), where names such as 'motsoala-bahale' [one who gives birth to brave men], 'mosala-hae' [one who remains home] and 'mosalale-likhutsana' [orphan minder] are coined in praise of a woman. In this way, MSP brings in a new dimension into the coining and use of deverbative eulogues as lithoko content. For example, 'motsoala-bahale', which translates into 'one who gives birth to brave men' as a descriptive name for Queen Elizabeth II, is an allusion to her social and political contribution, locally and internationally. As a mother she gave birth to Prince Charles, the heir to the English throne as well as nurturing other political leaders such as the Lesotho Monarch who are both 'bahale' [brave men] in terms of their leadership roles amongst their own people. The name can also be looked at as an expression of appreciation by the poet, for the role Queen Elizabeth II played in modelling some African leadership. This goes further to elevate women to the same level as lithoko did with men; of being heroines in their own right, as well as showing appreciation for their political contribution. In this way, MSP is not only playing host to eulogues from lithoko but it is also taking the style to another level; that of using deverbative names on women.

Names indicative of actions performed by heroes are not only used for humans in MSP but also for inanimate objects such as train, and textual items such as newspapers as in Elias and Hlalele (1970:140-143), Khaketla (1985:61-62) and Ramone (2001:39), to mention but a few. For example, in his poem entitled 'Seroala-nkhoana' [the helmet], Ramone (2001) praises a bulldozer and in stanza 4 line 4, he describes it thus:

4. U makatolle a chafo li katiloe,

[You are the unblocker of the blocked shafts]. (p. 39)

The name 'makatolle' [the one who unblocks] is derived from the verb 'katolla' [unblock]. The bulldozer is named as such owing to its work of digging up and pushing aside heavy rocks and rubble in shafts, in order to clear the work place for miners. It is worth noting that though deverbatively this is lithoko style, using a praise name for inanimate objects and female folk, as seen above, is a new phenomenon introduced by MSP. Though this new trend that MSP has introduced in the use of deverbative eulogues, deviates from the oral-formulaic norm where deverbative names were only coined for human heroes in lithoko, the trend is an indication of the poetic creativity amongst the poets and this helps the genre to grow in terms of style, content and devices (poetic).

\section{Metaphorical eulogues in modern Sesotho poetry}

There are also manifestations of lithoko intertextual metaphorical eulogues in MSP. Kunene (1971:37) describes metaphorical eulogues as names which distinguish the hero, associating him with a natural phenomenon known for its power, to the highest level of quality observed and applauded in the hero. Common in lithoko are wild animals and natural phenomena such as 'lightening associated with speed and deadly accuracy; the lion with strength, ferocity, majesty; the overarching sky with strength, elevated status, benevolence and fatherly protection to those below ...', amongst others (Kunene 1971:37). Kunene further indicates that it is on rare occasions amongst the Basotho that names of domestic animals, especially the bovine, are conferred on those being described; a pattern that is also noticed in MSP.

Chief Masopha is named after the eagle in Mangoaela (1957:38, line 23) to project his hunting skills which are mapped onto those of the eagle. The basis of this comparison is his sweeping off the cattle belonging to one of Gert Taaibosch's Griquas called Jacob in 1852 and 1853 (Damane \& Sanders 1974:118). It must be noted that even though the primary intention in naming Chief Masopha after the eagle is to project his eagle-like, unexpected snatching act, it goes further in highlighting the historical hunting expedition as shown above. Therefore, the name can also be looked at as a historical reference. Modern Sesotho poetry invokes this naming technique from lithoko as manifested in line 39 of the poem relating Matlakala's dream about how her father was run over by a car whilst in Johannesburg (Sentšo 1948):

39. Ke lefokotsane, maphatsi-phatsi a tsoa feta;

[It is the glimmering swallow that has just gone past]. (p. 9) 
'Lefokotsane' [swallow] is used as an analogy for the car that ran Matlakala's father over. The comparison is probably centred on the glimmer and the swift gliding movement of the swallow; qualities observed in the car. It is worth pointing out however, that MSP goes beyond playing host to lithoko by echoing the metaphorical eulogues and projecting the physical qualities of the object concerned (as intertexts). The poet this time around, although still using a natural phenomenon in the form of a bird, the swallow, the object of comparison is an inanimate object, a car; a form that lithoko never uses. This only shows the element of creativity and dynamism when it comes to poets in MSP. They do not only echo lithoko in terms of these naming eulogues, but they also take it to another level and give it a new dimension. It is here and in the examples that follow where we see MSP using prior texts, (lithoko in this case) as a source of meaning created through metaphors and for purposes of constructing itself as one of the six levels of intertextuality states, according to Bazerman (2005:3-4).

As Finnegan (1987:121) posits, 'praise poetry is also a vehicle for the recording of history as viewed by the poets'. By virtue of having lithoko content in the form of praise-names that make some historical references, MSP echoes lithoko not only in content, but also in principle as Finnegan has just stated. Evidence to this is also found in Bolebali (1951) where certain praise-names for King George VI conjure some historical events. The example is in the following line from Mokorosi's (1951) poem:

\section{Tlo, tamoleli, Rakhotso Konotetsi;}

[Come the rescuer, Father of Peace, the finest and strongest one]. (p. 4)

The reference to King George VI as the rescuer and father of peace may be owing to the continued protection Lesotho received even during his reign after Lesotho was declared a British protectorate on 12 March 1868. This came as a result of Moshoeshoe 1's appeal, through Sir Philip Wodehouse, in a letter dated 09 December 1867, addressed to Queen Elizabeth II, after a series of wars with the Orange River Sovereignty Afrikaners (Damane 1998:82). For King George VI to continue observing the protection protocol he inherited Lesotho, which occasioned him to intervene between Lesotho and the Afrikaners in order 'to rescue' ('ho namolela') Lesotho from her neighbour's threats, earning himself the name 'tamoleli' [the rescuer]. Since this act resulted in the maintenance of peace between Lesotho and her neighbour, Orange River Sovereignty, it earned him the second name 'Rakhotso' [father of peace].

The above examples of MSP hosting certain lithoko content is viewed as not only poetic advancement in as far as MSP is concerned, but also as a way of preserving and transmitting some historical events without necessarily going into history books.

Other forms of intertextual manifestations of lithoko in MSP are metaphorical eulogues of descent and place of origin.

\section{Descent}

Metaphorical eulogues concerned with the hero's descent and place of origin are a combination of a metaphorical reference that is followed by an associative reference connecting the hero 'to some famous ancestor or parent, to his clan, or, in a few instances, to his place of origin' (Kunene 1971:38). The following citation from Mangoaela (1957) is about Maama who is described thus in line 171 of his lithoko about the 1880 Gun war:

171. Sepumpuru sa Mokhachane, Maama,

[The boom of Mokhachane, Maama]. (p. 102)

In the first instance, Maama is referred to as the boom and he is later associated with Mokhachane, who happens to be his great grandfather. In this way, the hero (being Maama) is connected to his famous ancestral grandparent, Mokhachane, the father to Moshoeshoe 1 . This associative reference does not only bring into play Maama's kingship lineage as a historical fact, but also in some way, elevates and cements the social status of his royalty.

Alfaro (1996:270) observes that one of the hallmarks of intertextuality is that 'the textual past is always present through quotations or allusions in the work of such writers as Bacon, Shakespeare, Montaigne, Ronsard, Du Bellay, etc'. In this case the textual past present through allusions in MSP is in the form of metaphorical eulogues indicative of the hero's descent and historical events. Evidence of this is drawn from Khaketla (1985:1-4) in the poem entitled 'Ntoa ea Abisinia' [The Battle of Abyssinia] in which examples of intertextual manifestations of lithoko content in MSP, indicative of eulogues of descent and historical events are cited. The discussion here is centred on Mussolini and King George VI as examples of descent, and place of origin with historical allusions.

Mussolini was born Benito Amilcare Andrea on 29 July 1883, in Forli, Italy, and was assassinated on 28 April 1945. He was the leader of the National Fascist Party and was Prime Minister of the country from 1922 until his ousting in 1943. The Italian invasion of Ethiopia in 1935 happened under his leadership and command (Spartacus Educational n.d.). Mussolini is metaphorically referred to as 'Ntsukobokobo' [the eagle]. The name conjures not only his power but also his seniority in the then Italian military rankings and national hierarchy as the brief reference above has shown. The metaphorical eulogue is accompanied by an associative reference '... ea habo Sesare' [... from Caesar's family] (Khaketla 1985:1, line 9), which does not only relate him to one of his famous ancestors Julius Caesar, who was a Roman General in the 50s BC, but also makes an indirect reference to the Italian political leadership of the time.

Moreover, as the Italian leader who conquered Ethiopia in May 1935, he is properly associated with Julius Caesar, another Roman general and conqueror who was one of the most powerful Roman governors between 58 BC and 60 BC. Like Caesar, Mussolini was also a political, dictatorial ruler 
in a region which is now called Italy; a historical reference that is carried by Mussolini's praise-name. Mussolini is further portrayed as a Roman by descent originating from great Romans, where he is referred to as 'Tloloana sa Roma ...' translated as 'The Roman great grandson' (Khaketla 1985:3, line 93).

Besides conjuring some historical events such as the 1935 Ethiopian invasion in which Mussolini was involved, relating him to Caesar also denotes his ruthlessness with his enemies. For instance, it is stated that whilst expanding his reach, Caesar also displayed some ruthless tactics with his enemies as in one occasion, he waited for the water supply of his adversaries to run dry and then ordered the decapitation of the hands of the remaining survivors (Biography n.d.[a]). In a similar fashion, the use of mustard gas on Ethiopians in 1935 must have been the order from Mussolini as the leader (Khaketla 1985:2, lines 47-48).

Through these references, MSP echoes lithoko in terms of historical heroes, their descent and events surrounding them. It is in this way that lithoko as a parasite continues living in MSP through generations, and with them, its continuity in history.

\section{Place of origin}

Metaphorical eulogues here are followed by an associative reference connecting the hero to his place of origin as shown in the following example taken from Bereng Letsie's lithoko (Mangaoela 1957):

Tau ea mothati oa Qeme ...

[Lion of the mountain ledges of Qeme ...]. (p. 90, line 1)

In the first instance, Bereng is metaphorically referred to as a lion, probably to project his strength and ferocity to the audience. The metaphorical reference is followed by an adverbial phrase 'of the mountain ledges of Qeme', indicative of a place. This is the place where the hero hails from, or originates. He originates from Qeme, a village about $35 \mathrm{~km}$ in the Southern part of Maseru, the capital city of Lesotho, just beyond Moshoeshoe 1 International Airport.

The otherness as the intertexts are referred to, in relation to the above lithoko formulaic structures where the hero is associated with the place of origin, is identified from Section I of Mokorosi (1951:1, 3, 4 \& 6). The subject that is being explored in this Section I is 'Ketelo ea Motlotlehi' [His Majesty's visit], a historical event about the visit of King George VI of England to Lesotho in January 1947, during the regency of the Paramount Chieftainness 'Mantsebo' Seeiso. Examples of metaphorical references, indicating places of origin for King George VI, Chieftainess 'Mantsebo', Queen Victoria as well as Basotho as individuals and in their respective groups, have been noted. Nevertheless, the discussion focuses on metaphorical references which concern King George VI's place of origin as intertexts from lithoko.
King George VI was the son of King George V and Victoria May (Mary of Teck), born on 14 December 1895. He became king of the United Kingdom and the Dominions of the British Commonwealth from 11 December 1936 until his death on 06 February 1952 (Biography n.d.[b]). The following lines provide some of the instances in which King George VI is eulogised in references, relating him to Britain/ England or overseas as his place of origin:

4. Hlonepha Tlakatšooana la Engelane,
[Honour the English, Egyptian vulture]
58. Ngoan'a maoatleng, bosolla-thapi
[The child from the seas where fish swim aimlessly]
84. Re e'o bona Nakangoeli sa Britania.
[We are going to see the British Glow worm.]
116. Tlong re lokisetseng Britain Khosi,
[Come; let us prepare for the British King]
129. Tlakatšooana la metsing, setsoto,
[The White scavenger, the spectacle from the waters]

(Mokorosi 1951:1, 3, 4 \& 6)

Not only is Britain/England referred to as King George VI's place of origin through these lithoko-names, but also the seas where fish swim aimlessly and the waters, according to lines 58 and 129, respectively, all of which bear connotations to overseas. Connecting him with the seas or waters by referring to him as 'Ngoan'a maoatleng, bosolla-tlhapi' [The child from the seas where fish swim aimlessly] and 'Tlakatšooana la metsing' [The white scavenger from the waters] may have emanated from Basotho and some Africans' belief that a white man comes from the sea. The belief also comes from the fact that when Europeans first came to Africa and made contact with Africans, it was through the sea.

It is worth noting that by giving an account of the said historical event that involved the two most prominent figures in the political and social hierarchy of the two countries, England and Lesotho, MSP is already assuming a host position in relation to lithoko, which are viewed here as parasite. Firstly, by giving this historical account, MSP is not only echoing lithoko functionally as a text. Tšiu (2008:16) asserts that the 'recitation of praise poems is, in a sense, not only a transmission of the people's history', but also keeps alive the people's heroes and their history. This is supported by Ogunjimi (2005:205), who asserts that through oral poetry composition, African people have been able to keep the memory of their heroes alive in a form that appears to be 'a more natural custodian of such memory than modern written forms'.

It has been and still is through metaphorical references like the ones discussed above that not only are heroes, warriors, kings and queens celebrated, but also honoured and acknowledged for their outstanding contribution to their respective societies and humanity in general. Ogunjimi 
(2005:205) confirms this in saying: 'heroic poetry, like any of the other forms of traditional poetry, is ... employed to celebrate individuals, towns and lineages that had performed great feats during their lifetime'. Through playing host to some of these lithoko-names and oral-formulaic segments, modern Sesotho poetry is not only revealing historical moments, but also preserving and relating the historical stories that lithoko are so rich in.

\section{Conclusion}

The article set out to consider what it regards as echoes of lithoko in MSP through the lenses of intertextuality. Along with deverbative eulogues the article identified and discussed metaphorical eulogues or lithoko-names alluding to descent, place of origin, as part of lithoko content in MSP. The article also considered the aspect of historical allusions to certain events, occasions and stories. The analysis identified eulogical intertexts throughout the modern poetry spectra. In addition to being inspired by and based on historical events, some poems also rely heavily on eulogues to communicate their message just like lithoko. In some cases, direct segmental lifts from lithoko have been identified.

The identified lithoko-names and the oral-formulaic segments have been considered in terms of the historical figures, events or occasions they indirectly refer to. The analysis has finally affirmed the view that through the lithoko-names and their references, MSP has drawn quite significantly from lithoko, either directly or indirectly through the use of some lithoko principles and functions in its composition. The interrelation between lithoko and MSP revealed through the above analysis, therefore upholds the view that indeed 'we do not create original texts ex nihilo; texts are conceived in the sharing and interrelation with previous and future texts' (Scherer 2010:29). Modern Sesotho poetry as a text cannot be said to be original as it contains bits and pieces from lithoko as a text from the past. Therefore MSP, as Haberer (2007:58) quotes Barthes, is 'a tissue of quotations drawn from innumerable centres of culture'.

One of the important findings this discussion has made is how this host-parasite relationship has benefited both lithoko and MSP as texts. As a parasite, lithoko continue to live and be lived through in the ways that we have seen in MSP as a genre, on the one hand. On the other hand, MSP as a host, has given itself a face lift not only in terms of poetic features such as metaphorical eulogues that add flavour, melody and style but also in the historical content. The analysis has also provided better insight into MSP for learners and teachers as well as poetry appreciators in general, so that they can approach poetry better informed about its poetic style, content and techniques. In this way, all these parties can have an informed appreciation of MSP. In turn MSP will be better appreciated and understood.

\section{Acknowledgements}

This article is partially based on the author's thesis for the degree of Doctor of Philosophy at the University of Kwazulu-Natal, South Africa, with promotors, Prof. N.N. Mathonsi and Prof. N.S. Zulu, received 2016, available here: http://hdl.handle.net/10413/14204.

We wish to express gratitude to the Department of Languages, School of Arts, College of Humanities, University of KwaZulu-Natal for the scholarship provided and its continued financial support to publish the work.

\section{Competing interests}

The authors declare that they have no financial or personal relationships that may have inappropriately influenced them in writing this article.

\section{Authors' contributions}

K.C.M. and N.M. contributed equally to this research article.

\section{Ethical considerations}

This article followed all ethical standards for research.

\section{Funding information}

This research received no specific grant from any funding agency in the public, commercial or not-for-profit sectors.

\section{Data availability}

The authors confirm that the data supporting the findings of this study are available within the article.

\section{Disclaimer}

The views and opinions expressed in this article are those of the authors and do not necessarily reflect the official policy or position of any affiliated agency of the authors.

\section{References}

Abrams, M.H., 1999, A glossary of literary terms, Harcourt Brace, New York, NY.

Alfaro, M.J.M., 1996, 'Intertextuality: Origins and development of the concept', Atlantis 18(1-2), 268-285.

Allen, G., 2011, Intertextuality, 2nd edn., Routledge, New York, NY.

Bazerman, C., 2005, Intertextuality: How texts rely on other texts, University of California, Santa Barbara, CA.

Bereng, D.T.C., 1931, Lithothokiso tsa Moshoeshoe le tse ling, 1st edn., Morija Sesuto Book Depot, Morija.

Bereng, P.M. \& Lehloenya, L.P., 2006, Haboo, Lilala Publications, Maseru.

Biograpghy, n.d.(a), Julius Ceasar, viewed n.d., from https://www.biography.com/ political-figure/julius-caesar.

Biograpghy, n.d.(b), George VI, viewed n.d., from https://www.biography.com/ royalty/george-vi.

Cuddon, J.A., 1998, A dictionary of literary terms \& literary theory, 4th edn., Penguin Books, London.

Damane, M., 1998, Histori ea Lesotho, Morija Sesuto Depot, Morija.

Damane, M. \& Sanders, P.B., 1974, Lithoko Sotho Praise-Poems, Oxford University Press, New York, NY. 
Elias, A.T. \& Hlalele, J.P., 1970, Fela sa Ncheme, 2nd edn., Mazenod Book Centre, Mazenod.

Finnegan, R., 1987, Oral literature in Africa, Oxford University Press, Nairobi.

Graham, A., 2000, Intertextuality, Routledge, London.

Graham, A., 2003, Roland Barthes, Routledge, New York, NY.

Haberer, A., 2007, 'Intertextuality in theory and practice', Literatura 49(5), 54-67. https://doi.org/10.15388/Litera.2007.5.7934

Khaketla, B.M., 1985, Lipshamathe, 1st edn., Morija Printing Works, Morija.

Kunene, D.P., 1971, Heroic poetry of the Basotho, Clarendon Press, Oxford.

Lenake, J.M., 1984, The poetry of K.E. Ntsane, J.L. Van Schaik, Pretoria.

Maimane, K.C., 2016, 'Confluences of Lithoko, religious and traditional beliefs and western poetry in modern Sesotho poetry (MSP): An intertextual perspective', $\mathrm{PhD}$ thesis, Dept. of Department of Languages, University of Kwazulu-Natal.

Mangoaela, Z.D., 1957, Lithoko tsa Marena a Basotho, 6th edn., Morija Sesuto Book Depot, Morija.

Mokorosi, E.S., 1951, Bolebali, Morija Sesuto Book Depot, Morija.
Ogunjimi, M., 2005, Introduction to African oral literature and performance, African World Press, Trenton, NJ.

Porter, J.E., 2009, Intertextuality and the discourse community, viewed 22 February 2012, from http://discoursecommunities.wordpress.com/.

Ramone, M.S., 2001, 'Na ke Mosotho, Longman Lesotho, Maseru.

Scherer, A.S., 2010, 'Explicit intertextuality in science popularisation news', Revista AO PE DA LETRA 12(2), 25-49.

Simandan, V.M., 2010, 'Julia Kristeva's concepts of intertextuality', viewed 18 May 2012 from https://www.simandan.com/kristevas-concepts-of-intertextuality/.

Sentšo, D., 1948, Matlakala, Morija Sesuto Book Depot, Morija.

Shanoda, M., 2012, 'Metaphor and intertextuality: A cognitive approach to intertextual meaning-making in metafictional fantasy novels', International Research in Children's Literature 5(1), 81-96. https://doi.org/10.3366/ircl.2012.0045

Spartacus Educational, n.d., Benito Mussolini, viewed n.d., from https://spartacuseducational.com/2WWmussolini.htm.

Tšiu, M., 2008, 'Basotho Oral Poetry at the beginning of the 21st Century', vol. 1, Unpublished doctoral thesis, University of South Africa, Pretoria. 